\title{
Towards Localized Tactile Feedback on Touch Surfaces: Finite Element Analysis of a Vibrating Touch Screen Actuated by Piezo Patches
}

\author{
Nur Lara Alpdoğan ${ }^{1}$, Mehmet Ayyıldız ${ }^{2 *}$ \\ ${ }^{1}$ Istanbul Bilgi University, Faculty of Engineering and Natural Sciences, İstanbul, Türkiye (ORCID: 0000-0003-4389-7519), lara.alpdogan@bilgiedu.net \\ 2* Istanbul Bilgi University, Faculty of Engineering and Natural Sciences, İstanbul, Türkiye (ORCID: 0000-0003-3411-6215), mehmet.ayyildiz@ bilgi.edu.tr
}

(International Symposium on Multidisciplinary Studies and Innovative Technologies (ISMSIT) 2021 - 21-23 October 2021)

(DOI: 10.31590/ejosat.1014803)

ATIF/REFERENCE: Alpdogan, N. L. \& Ayyildiz, M. (2021). Towards Localized Tactile Feedback on Touch Surfaces: Finite Element Analysis of a Vibrating Touch Screen Actuated by Piezo Patches. European Journal of Science and Technology, (29), 214218.

\begin{abstract}
Surface haptics technologies offer an augmented user experience by providing a unique and distinctive interaction between the finger and touchscreen. In this study, we focus on a touch screen design to display vibrotactile tactile feedback to the user through piezo patches located on its surface. We investigated the effects of boundary conditions, piezo configurations, and materials of the touch surface and piezo patches that will achieve the highest deformation on the touch surface, considering the most sensible human tactile perception frequency using the ANSYS FEM software package. In our analysis, we used three different touch surface and piezo patch materials, three different boundary conditions, four different piezo patch locations, and three different touch surface thicknesses. The results showed that the boundary conditions and thickness of the glass have a significant effect on the first natural frequency of the touch surface, and the results leading to best human tactile perception were obtained by fixing four piezo patches at four sides of the touch surface. Based on the determined configuration in the modal analyses, we performed a response surface optimization study to estimate the geometry of the touch surface (width, height, thickness), which will result in maximum deformation on the touch surface. We achieved the best configuration (max total deformation at about $250 \mathrm{~Hz}$ first modal frequency) with $160 \times 90 \times 0.28 \mathrm{~mm}$ and 190 $\times 110 \times 0.4 \mathrm{~mm}$ dimensions. In the future, we will develop models to render localized tactile feedback on a touchscreen-based on piezo patches operating at various combinations (i.e., sequence, amplitude, frequency), which will be predicted based on the FEM simulations.
\end{abstract}

Keywords: Surface Haptics, Vibrotactile Feedback, Touch Screen, Finite Element Analysis, Piezo Patches

\section{Dokunmatik Yüzeylerde Yerel Dokunsal Geri Bildirime Doğru: Piezo Yamalar Tarafından Çalıştırılan Titreşimli Bir Dokunmatik Ekranın Sonlu Elemanlar Analizi}

$\ddot{O} z$

Yüzey haptik teknolojileri, parmak ve dokunmatik ekran arasında benzersiz ve ayırt edici bir etkileşim sağlayarak artırılmış bir kullanıcı deneyimi sunar. Bu çalışmada, yüzeyinde bulunan piezo yamalar aracılığıyla kullanıcıya vibrotaktil dokunsal geri bildirim gösteren bir dokunmatik ekran tasarımına odaklanılmıştır. ANSYS FEM yazılım paketini kullanarak, dokunmatik yüzeyde en yüksek deformasyonu sağlayacak ekran ve piezo yama malzemelerinin, sınır koşullarının ve piezo konfigürasyonunun etkilerini insan dokunsal algısının en hassas olacağı frekansı göz önünde bulundurarak araştırdık. Analizimizde üç farklı dokunmatik yüzey ve piezo yama malzemesi, üç farklı sınır koşulu, dört farklı piezo konumu ve üç farklı dokunmatik yüzey kalınlığı kullandık. Sonuçlar, camın sınır koşullarının ve kalınlığının dokunmatik yüzeyin ilk doğal frekansı üzerinde önemli bir etkiye sahip olduğunu ve dokunmatik yüzeyin dört tarafına dört piezo yamasının sabitlenmesiyle en iyi insan dokunma algısını sağlayacak sonuçların elde edildiğini gösterdiModal analizlerde belirlenen konfigürasyon baz alınarak, dokunmatik ekranda maksimum deformasyonun başarılacağ 1 dokunmatik ekranın geometrisini (genişlik, yükseklik, kalınlık) hesaplamak için bir tepki yüzeyi optimizasyonu çalışması gerçekleştirdik. $160 \times 90 \times 0.28 \mathrm{~mm}$ ve $190 \times 110 \times 0.4 \mathrm{~mm}$ boyutlarıyla en iyi konfigürasyonu (yaklaşı $250 \mathrm{~Hz}$ birinci modal frekansta maksimum toplam deformasyon) elde ettik. Gelecekte, FEM simülasyonlarının sonuçlarına bağlı olarak tahmin edilecek değişik piezo kombinasyonlarında (tahrik sırası, genliği, ve frekansı) dokunmatik yüzeylerde yerelleştirilmiş dokunsal geri bildirim oluşturacak modeller geliştireceğiz.

Anahtar Kelimeler: Yüzey Haptiği, Vibrotaktil Dokunsal Geri Bildirim, Dokunmatik Ekran, Sonlu Elemanlar Analizi, Piezo Yamalar.

*Corresponding Author: mehmet.ayyildiz@ bilgi.edu.tr 


\section{Introduction}

Today, touch screens replace the mechanical buttons, keys, and knobs used in conventional devices. Surface haptics, providing tactile feedback on touch surfaces, is a recent research field that is accumulating a lot of attention due to the widespread usage of touchscreens. There are different methods such as electrovibration, ultrasonic actuation, and vibrotactile actuation to augment user experience on touch surfaces [1]. In electrostatic actuation, the friction is modulated between the fingertip and a touch surface. An electrostatic attraction force is produced between the surface and finger when an alternating voltage is applied to the conductive layer of a capacitive touchscreen. Hence, there is no mechanical vibration on the touch surface. In ultrasonic actuation, the touch surface is stimulated mechanically at an ultrasonic resonance frequency that generates a thin layer of air gap between the finger and the touch surface. Therefore, the sliding friction of the finger is reduced as opposed to the sliding friction in electrovibration. In vibrotactile actuation, a vibration signal at a frequency that is detectable by the user's fingertip (usually below $500 \mathrm{~Hz}$ ) is displayed through a touch surface. The simplest and most common example for this technology is the touch surface of a mobile phone, which is typically actuated by a low-cost vibration motor to notify the user about the incoming calls and provide confirmation for button clicks.

Adding tactile feedback to the touch surfaces can augment the experience of the user and provide an additional layer of information through the haptic channel. In this study, we will focus on vibrotactile actuation, which involves using small and lightweight actuators on the touch surface to provide tactile feedback to the user. So far, various methods have been utilized to display tactile feedback on touch surfaces. Baylan et al. [2] simulated different layouts by conducting finite element analyses using the ABAQUS software and compared the amplitude of the vibrations on the touchscreen by placing a various number of piezoelectric actuators on different configurations. Then, they computed the first four resonant frequencies in three different boundary conditions of the touch screen to determine the optimal configuration for piezo patches. Sar1 et al. [3] investigated the effects of voltage, frequency, number, and position of piezo patches on the surface vibrations of the touch screen to produce high-amplitude vibrations. They reported that as the number of active piezo patches increased, the maximum amplitude obtained on the touchscreen was also increased. Ak et al. [4] explored the vibration modes of the screen using different piezo and touch screen materials using the finite element method. Their results showed that Gorilla Glass led to the best vibration characteristics among Gorilla Glass, Sapphire, and Alon. Also, they observed that the number of the piezo elements changed the mode shapes of the touch screen. Hudin et al. [5] implemented a time-reversal of acoustic waves approach to produce localized tactile stimuli on a transparent surface using piezoelectric actuators. They conducted a user study to demonstrate their capability to provide perceivable localized tactile feedback. Enferad et al. [6] used the time-reversal method to produce velocity fields on touch surfaces using piezoelectric patches. They calculated the required voltage and dispatched them among piezo elements to produce localized tactile feedback by modal superposition.

This study investigates the effects of boundary conditions, piezo configuration, and materials of the touch surface and piezo patches to design a vibrotactile touchscreen using the ANSYS software. First, we performed modal analyses to determine optimum material types and boundary conditions for the glass and piezo patches. Then, we performed response surface analysis to determine the optimum geometry of the glass (width, height, and thickness). In these analyses, we aimed to obtain the highest deformation amplitude on the glass at the vicinity of 250 $\mathrm{Hz}$, where human tactile perception is maximized [7]. These results will guide us in developing models to provide localized tactile feedback to users by actuating piezo patches (i.e., at different combinations, sequences, and amplitudes). Hence, independent from the actual position of the piezo actuators, we can generate localized stimulation on the touch surface by superposing modal forces at variable ratios.

\section{Material and Method}

\subsection{Modal Analyses}

We performed our modal analyses using ANSYS Mechanical. In the first phase, we designed our system in ANSYS DesignModeler, as shown in Fig. 1. The gray rectangular area shows the glass, while the yellow circles represent piezo patches. The dimensions of the touch surface were $160 \times 90 \times 0.3 \mathrm{~mm}$, and the diameter and thickness of the piezo patches were $25 \mathrm{~mm}$ and $0.2 \mathrm{~mm}$, respectively. Then, material properties for the touch surface (glass, Gorilla Glass, and Sapphire) and piezo patches (PZT-4, PZT-5A, and PiezoCeramic) were entered in the engineering data as shown in Table 1 and Table 2, respectively. The element size was 0.001 meters in the meshing; average, minimum and maximum element quality was $0.52746,0.30895$, and 0.89052 , respectively. In the next stage, we performed modal analyses to evaluate the first natural frequencies of the system where the amplitude of the maximum deformation is highest. Vardar et al. [7] reported that showed that the Pacinian channel was the leading psychophysical channel in charge of the detection of tactile stimuli, which was most effective at high frequencies around $250 \mathrm{~Hz}$. Therefore, the first natural frequencies should be near $250 \mathrm{~Hz}$ so that mechanoreceptors in the fingertips can efficiently feel the vibrotactile feedback. Mode shapes and natural frequencies resulting from piezo actuators' interactions with touch surfaces were tested in three boundary conditions as given in Fig. 2. Also, different piezo patch configurations (e.g., numbers and materials), as well as the effect of the different touch surfaces and piezo materials, were investigated in our analyses.

Table 1. Material properties of the touch surface used in the simulations

\begin{tabular}{l|c|c|c}
\hline Materials & $\begin{array}{c}\text { Young's Modulus } \\
(\mathbf{G P a})\end{array}$ & $\begin{array}{c}\text { Density } \\
\left(\mathbf{k g} / \mathbf{m}^{\mathbf{3}}\right)\end{array}$ & $\begin{array}{c}\text { Poisson's } \\
\text { Ratio }\end{array}$ \\
\hline Glass & 76.7 & 2430 & 0.21 \\
\hline Gorilla Glass & 73 & 2500 & 0.23 \\
\hline Sapphire & 435 & 3980 & 0.29 \\
\hline
\end{tabular}


Table 2. Material properties of piezo patches used in the simulations

\begin{tabular}{l|c|c|c|c}
\hline Properties & Abbreviation & PZT-4 & PZT-5A & $\begin{array}{l}\text { Piezo- } \\
\text { Ceramic }\end{array}$ \\
\hline $\begin{array}{l}\text { Density } \\
\left(\mathrm{g} / \mathrm{cm}^{3}\right)\end{array}$ & $\rho$ & 7.60 & 7.88 & 7.5 \\
\hline \multirow{3}{*}{$\begin{array}{l}\text { Young's } \\
\begin{array}{l}\text { Modulus } \\
(\text { GPa })\end{array}\end{array}$} & $\mathrm{E}_{\mathrm{XY}}$ & 81.3 & 61.0 & 78.6 \\
\cline { 2 - 5 } & $\mathrm{E}_{\mathrm{XZ}}$ & 81.3 & 61.0 & 78.6 \\
\hline \multirow{3}{*}{$\begin{array}{l}\text { Shear } \\
\text { Modulus } \\
(\text { GPa })\end{array}$} & $\mathrm{G}_{\mathrm{XY}}$ & 30.6 & 22.6 & 30.0 \\
\cline { 2 - 5 } & $\mathrm{G}_{\mathrm{YZ}}$ & 25.6 & 21.1 & 26.0 \\
\hline \multirow{3}{*}{$\begin{array}{l}\text { Poisson's } \\
\text { Ratio }\end{array}$} & $\mathrm{G}_{\mathrm{XZ}}$ & 25.6 & 21.1 & 26.0 \\
\cline { 2 - 5 } & $\mathrm{v}_{\mathrm{XY}}$ & 0.33 & 0.35 & 0.28 \\
\cline { 2 - 5 } & $\mathrm{v}_{\mathrm{XZ}}$ & 0.43 & 0.38 & 0.45 \\
\hline
\end{tabular}

\subsection{Response Surface Optimization}

The response surface methodology (RSM) investigates the relationship between input and output variables. The main aim of RSM is basically to try to get an optimal surface from the responses given in the face of independent variables [8]. Parameter selections were adjusted according to the width, height, and thickness of the touch surface in the range of tablets, laptops, and mobile phones available in the market. The optimization objective was seeking the first natural frequency of the overall body at $250 \mathrm{~Hz}$ while obtaining the maximum deformation on the touch surface. In this way, we can estimate the dimensions of the touch surface, providing the best configuration for the optimum human tactile perception. The upper and lower values of the touch surface's width, height, and thickness were $120-330 \mathrm{~mm}, 60-200 \mathrm{~mm}$, and 0.27-0.5 mm, respectively.

\section{Results and Discussion}

\subsection{Modal Analyses}

The results of modal analyses showing the first modal frequencies of the touchscreen having different thicknesses, boundary conditions, and piezo configurations were reported in Table 3, Table 4, and Table 5, respectively. Table 3 showed that increasing the thickness of the touch surface increases the first modal frequency of the system. The effect of using different piezo patches was not significant in the results. However, using sapphire glass substrate led to about a 1.8-fold increase in the first natural frequency of the system. In Table 4, we can see that the 4-edge fixing boundary condition resulted in first natural frequencies in the vicinity of $250 \mathrm{~Hz}$ for glass and Gorilla Glass substrates. Table 5 shows the effect of different piezo

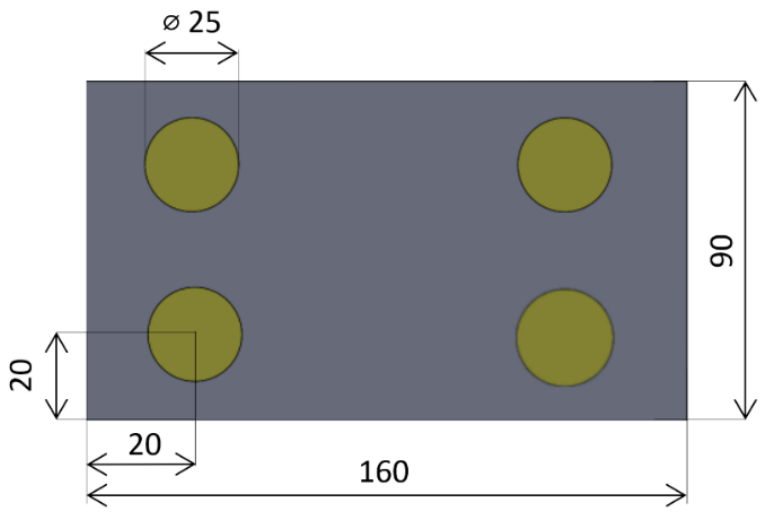

Figure 1. Design of touch surface with tactile feedback: the gray area represents the transparent touch surface, while the circles correspond to piezo patches. The unit of the dimensions is in millimeters.

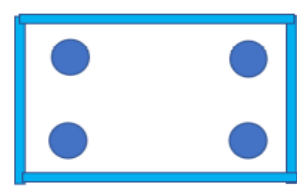

4 Edge Fix

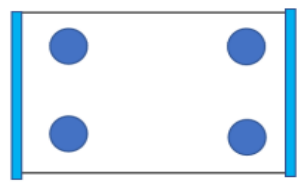

2 Vertical Fix

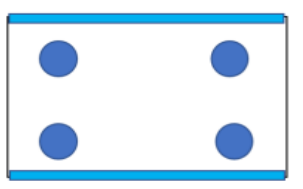

2 Horizontal Fix

a)

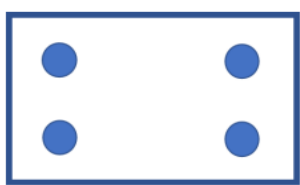

4 Piezo

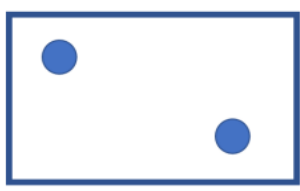

2 Piezo Diagonal

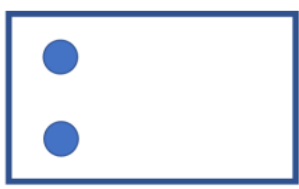

2 Piezo Up and Down

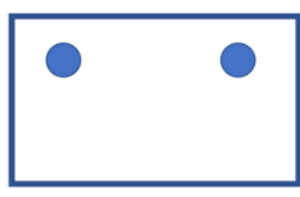

2 Piezo Side by Side b)

Figure 2. a) Boundary conditions of the touch surface and b) different piezo patch configurations on the touch surface. 
Table 3. The first modal frequencies of the touch surface with glass, Gorilla Glass, and Sapphire substrates at different touch surface thicknesses

\begin{tabular}{c|c|c|c|c|c|c|c|c|c}
\hline \multirow{2}{*}{$\begin{array}{c}\text { Touch } \\
\begin{array}{c}\text { Surface } \\
\text { Thickness } \\
(\mathbf{m m})\end{array}\end{array}$} & \multicolumn{3}{|c|}{ PZT-4 (Hz) } & \multicolumn{3}{c|}{ PZT-5A (Hz) } & \multicolumn{3}{c}{ Piezo-Ceramic (Hz) } \\
\cline { 2 - 10 } & Glass & Gorilla & Sapphire & Glass & Gorilla & Sapphire & Glass & Gorilla & Sapphire \\
\hline 0.1 & 88 & 87 & 150 & 86 & 85 & 166 & 88 & 90 & 155 \\
\hline 0.3 & 246 & 255 & 456 & 245 & 253 & 457 & 251 & 259 & 457 \\
\hline 0.6 & 483 & 500 & 903 & 482 & 498 & 902 & 487 & 498 & 903 \\
\hline
\end{tabular}

Table 4. The first modal frequencies of the touch surface with glass, Gorilla Glass, and sapphire substrates at three different boundary conditions

\begin{tabular}{c|c|c|c|c|c|c|c|c|c}
\hline \multirow{2}{*}{$\begin{array}{c}\text { Boundary } \\
\text { conditions }\end{array}$} & \multicolumn{3}{|c|}{ PZT-4 (Hz) } & \multicolumn{3}{c|}{ PZT-5A (Hz) } & \multicolumn{3}{c}{ Piezo-Ceramic (Hz) } \\
\cline { 2 - 10 } & Glass & Gorilla & Sapphire & Glass & Gorilla & Sapphire & Glass & Gorilla & Sapphire \\
\hline 4 Edge Fix & 246 & 255 & 456 & 245 & 253 & 554 & 251 & 259 & 457 \\
\hline 2 Vertical Fix & 69 & 72 & 126 & 69 & 71 & 126 & 72 & 74 & 129 \\
\hline 2 Horizontal Fix & 195 & 201 & 378 & 194 & 201 & 375 & 205 & 212 & 388 \\
\hline
\end{tabular}

Table 5. The first modal frequencies of the touch surface with glass, Gorilla Glass, and Sapphire substrates at the different number and locations of piezo patches

\begin{tabular}{c|c|c|c|c|c|c|c|c|c}
\hline $\begin{array}{c}\text { Number and } \\
\text { Location of Piezo } \\
\text { Patches }\end{array}$ & \multicolumn{3}{|c|}{ PZT-4 (Hz) } & \multicolumn{3}{c|}{ PZT-5A (Hz) } & \multicolumn{3}{c}{ Piezo-Ceramic (Hz) } \\
\cline { 2 - 11 } & Glass & Gorilla & Sapphire & Glass & Gorilla & Sapphire & Glass & Gorilla & Sapphire \\
\hline 4 Piezo & 246 & 255 & 456 & 245 & 258 & 457 & 251 & 253 & 457 \\
\hline 2 Piezo Up and Down & 249 & 254 & 455 & 249 & 269 & 458 & 244 & 259 & 454 \\
\hline 2 Piezo Diagonal & 246 & 260 & 455 & 248 & 253 & 457 & 245 & 258 & 459 \\
\hline 2 Piezo Side by Side & 261 & 261 & 458 & 254 & 298 & 459 & 254 & 258 & 454 \\
\hline
\end{tabular}

configurations, such as different numbers and locations of piezo patches. The results showed that using various piezo configurations was insignificant in terms of the first modal natural frequency. These results suggested that a touch surface thickness of $0.3 \mathrm{~mm}$ was optimum when glass or Gorilla was selected as the touch surface substrate. It was also shown that the effect of using different piezo patch materials is not significant.

Moreover, selected piezo patch configurations (Table 5) did not lead to significantly different results in the first modal frequency. Fig. 3 showed the first mode shape deformation when four pieces of piezo-ceramic material piezo patches were fixed to 4 edges on the glass substrate. Our results are in agreement with the finding reported in the literature. Ak et al. [4] Gorilla Glass, Sapphire and Alon have selected the Gorilla Glass material as the best material by comparing the vibration modes of the touch screen materials. In our study, we also obtained the best results with a touch surface made of Gorilla Glass and glass substrates (see Table 3). Baylan et al. [2] studied the resonant frequencies of three different boundary conditions. They reported that fixing the touchscreen from four edges led to higher natural frequencies than other conditions similar to our findings (see Table 4). Sar1 et al. [3] observed that as the number of active piezo increases, the maximum amplitude values obtained in the experimental analysis increase. This finding is also compatible with our results reported in Table 4 . We obtained the best results when four piezo patches are fixed at the corners. Although, increasing the number of piezo patches does not affect the first natural freqency of the system in Table 5, the amplitude of the deformation on the touch surface increases.

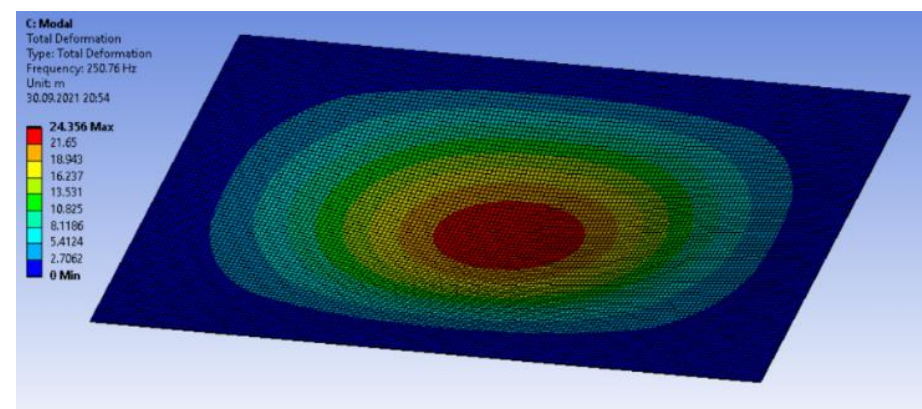

Figure 3. An exemplar figure showing the first mode shape deformation (dimension: $160 \times 90 \times 0.3 \mathrm{~mm}$; touch surface material: glass; piezo material: piezo-ceramic)

\subsection{Response Surface Optimization}

Based on the results of the modal analyses in the previous section, the dimensions of the touch surface were optimized in the response surface optimization analyses by maximizing the maximum deformation of the touch surface while seeking 250 $\mathrm{Hz}$ for the first modal frequency of the system. We used four piezo-ceramic piezo patches fixed on the edges of the glass substrate since we obtained the first modal frequency results at the vicinity of $250 \mathrm{~Hz}$ under these conditions in the previous analyses. The maximum total deformation and first natural frequency of the system at different geometric dimensions of the touch surface are presented in Table 6. Considering the aspect ratio standards of $4: 3$ and 16:9 in most devices, the selection should be made by considering the obtained configuration's 
aspect ratio (width/height). In this case, $160 \times 90 \times 0.28 \mathrm{~mm}$ and $190 \times 110 \times 0.4 \mathrm{~mm}$ provided a good match for $16: 9$ screen ratio.

Table 6. The response surface optimization analysis results show the dimensions of the touch surface (width, height, thickness) as a function of the maximum total deformation and first natural frequencies of the system.

\begin{tabular}{|c|c|c|c|c|}
\hline $\begin{array}{c}\text { Width } \\
(\mathbf{m m})\end{array}$ & $\begin{array}{c}\text { Height } \\
(\mathbf{m m})\end{array}$ & $\begin{array}{c}\text { Thickness } \\
(\mathbf{m m})\end{array}$ & $\begin{array}{c}\text { Max. Total } \\
\text { Deformation } \\
(\mathbf{m m})\end{array}$ & $\begin{array}{c}\text { First } \\
\text { Natural } \\
\text { Frequency } \\
(\mathbf{H z})\end{array}$ \\
\hline 120 & 125 & 0.38 & 20727 & 253 \\
\hline 330 & 125 & 0.38 & 12263 & 148 \\
\hline 225 & 125 & 0.5 & 13202 & 208 \\
\hline 170 & 90 & 0.3 & 23730 & 245 \\
\hline 270 & 100 & 0.4 & 15044 & 241 \\
\hline 300 & 200 & 0.27 & 11632 & 52 \\
\hline 327 & 53 & 0.3 & 22409 & 550 \\
\hline 160 & 90 & 0.28 & 24410 & 251 \\
\hline 180 & 100 & 0.3 & 22662 & 187 \\
\hline 145 & 110 & 0.5 & 17625 & 317 \\
\hline 165 & 95 & 0.3 & 23403 & 227 \\
\hline 217 & 85 & 0.32 & 21099 & 258 \\
\hline 120 & 70 & 0.3 & 29951 & 426 \\
\hline 250 & 140 & 0.3 & 15332 & 100 \\
\hline 180 & 100 & 0.28 & 22662 & 187 \\
\hline 160 & 85 & 0.45 & 16645 & 311 \\
\hline 215 & 115 & 0.35 & 17009 & 172 \\
\hline 200 & 84 & 0.32 & 22196 & 276 \\
\hline 310 & 180 & 0.4 & 10394 & 80 \\
\hline 190 & 110 & 0.4 & 17564 & 245 \\
\hline & & & & \\
\hline
\end{tabular}

\section{Conclusions and Recommendations}

We performed modal and response surface analyses using ANSYS to design a touchscreen providing vibrotactile haptic feedback. First, we conducted modal analyses to determine the best boundary conditions and material types of the touchscreen so that we can obtain the first modal frequency of the system at the vicinity of $250 \mathrm{~Hz}$ at which the optimum human vibrotactile perception is achieved. The results showed that using glass and Gorilla Glass materials as the touch surface's substrate and utilizing four piezo patches fixed on the edges resulted in the first natural frequencies closest to the desired frequency. Then, we performed an optimization study to determine the touch surface's geometry (width, height, thickness) which leads to the maximum deformation in the system while seeking $250 \mathrm{~Hz}$ in the first natural frequency in response surface optimization analyses. Considering the aspect ratio standards of the touchscreens, we found the best configuration with $160 \times 90 \mathrm{x}$ $0.28 \mathrm{~mm}$ and $190 \times 110 \times 0.4 \mathrm{~mm}$ dimensions. In the future study, we plan to develop models to display localized tactile feedback on touchscreen-based on running piezo patches at different combinations (i.e., sequence, amplitude, frequency) estimated by FEM simulations.

\section{References}

[1] Basdogan, C., Giraud, F., Levesque, V., \& Choi, S. (2020). s, 13(3), 450-470.
[2] Baylan, B., Aridogan, U., \& Basdogan, C. (2012, June). Finite element modeling of a vibrating touch screen actuated by piezo patches for haptic feedback. In International Conference on Human Haptic Sensing and Touch Enabled Computer Applications (pp. 47-57).

[3] Sari, G., Akgül, M. B., Kirişken, B., Ak, A. F., \& Akiş, A. A. (2017, July). An experimental study of a piezoelectrically actuated touch screen. In 2017 8th International Conference on Mechanical and Aerospace Engineering (ICMAE) (pp. 753-758). IEEE.

[4] Ak, A. F., Sari, G., Akgül, M. B., Kirişken, B., \& Akiş, A. A. (2017, July). Numerical analysis of vibrating touch screen actuated by piezo elements. In 2017 8th International Conference on Mechanical and Aerospace Engineering (ICMAE) (pp. 775-779). IEEE.

[5] Hudin, C., Lozada, J., \& Hayward, V. (2013, April). Localized tactile stimulation by time-reversal of flexural waves: Case study with a thin sheet of glass. In 2013 World Haptics Conference (WHC) (pp. 67-72). IEEE.

[6] Enferad, E., Giraud-Audine, C., Giraud, F., Amberg, M., \& Semail, B. L. (2019). Generating controlled localized stimulations on haptic displays by modal superimposition. Journal of Sound and Vibration, 449, 196213.

[7] Vardar, Y., Güçlü, B., \& Basdogan, C. (2017). Effect of waveform on tactile perception by electrovibration displayed on touch screens. IEEE transactions on haptics, 10(4), 488499.

[8] Khuri, A. I., \& Mukhopadhyay, S. (2010). Response surface methodology. Wiley Interdisciplinary Reviews: Computational Statistics, 2(2), 128-149. 